\title{
IMPACTOS DA INFILTRAÇÃO DA VINHAÇA DE CANA NO AQÜÍFERO BAURU
}

\author{
S.Hassuda ${ }^{1}$ \\ A.da C.Rebouças ${ }^{2}$ \\ R.C.de A.Cunha ${ }^{3}$
}

A área estudada está localizada no município de Novo Horizonte, situado no centro-oeste do Estado de São Paulo. Na região, ocorrem sedimentos cretáceos do Grupo Bauru que constituem um aqüífero livre e poroso, explorado para fins de abastecimento doméstico e industrial.

Sobre este aqüífero, cuja extensão no Estado de São Paulo é de $104.000 \mathrm{~km}^{2}$, a atividade canavieira tem apresentado um grande crescimento, fazendo com que um grande volume de vinhaça se infiltre no solo e cause uma considerável poluição hídrica, já considerada crítica em certas áreas.

A produção nacional de álcool é de 11 milhões de $\mathrm{m}^{3}$, atualmente, o qual gera aproximadamente 144 milhões de $\mathrm{m}^{3}$ de efluente, denominado vinhaça. O Estado de São Paulo, onde se encontram 153 indústrias açúcar-alcooleiras, é responsável por $60 \%$ desta produção.

Admitindo-se a geração de 12 litros de efluente por litro de álcool produzido, DBO do efluente igual a $20 \mathrm{~g} / \mathrm{l}$, duração da safra de 150 dias e demanda equivalente de $54 \mathrm{~g}$ DBO/habitante/dia, a carga poluidora oriunda da vinhaça das indústrias alcooleiras corresponde a uma população de 329 milhões de habitantes, equivalente, portanto, a 2,5 vezes a população nacional. Este quadro agrava-se ainda mais no Estado de São Paulo, onde a carga poluidora corresponde aproximadamente a 6 vezes a população do Estado. Além disso, $43 \%$

\footnotetext{
Instituto Geológico, São Paulo.

2 Departamento de Geologia Econômica e Geofísica Aplicada, Instituto de Geociências/USP, São Paulo.

${ }^{3}$ Companhia Estadual de Tecnologia Ambiental, São Paulo.
} 
dessa carga está no domínio do aqüífero Bauru.

Este trabalho enfoca a problemática da infiltração da vinhaça numa área piloto do aqǘfero Bauru. Seu objetivo básico foi o desenvolvimento de metodologia de campo para determinação do impacto dessa prática.

A área em questão é de propriedade da Usina São José da Estiva, que passou a operá-la na safra 1975/1976. Nesta área foram infiltrados aproximadamente $348.000 \mathrm{~m}^{3} /$ ano de vinhaça até 1984/1985. Atualmente, recebe o produto somente nos dia de chuva, quando o acesso às áreas de fertirrigação torna-se impossível. A vinhaça é depositada em tanques escavados nos locais de cotas mais elevadas e distribuída por gravidade pela zona de infiltração, através de sulcos ou canais.

A aplicação de técnicas geofísicas permitiu a correta instalação de piezômetros. Os dados geofísicos relativos à aplicação dos métodos da eletrorresistividade e eletromagnético indutivo, obtidos a partir de caminhamento, se equivalem em termos de precisão e nível de informação. Porém as medidas do método eletromagnético indutivo foram extremamente mais rápidas, o que representa uma grande vantagem quando considerados os fatores custo e prazo.

Os dados da análise físico-química das águas subterrâneas obtidas nas cacimbas e piezômetros permitiram verificar a ocorrência da alteração da qualidade da água subterrânea com a infiltração da vinhaça.

Os valores de $\mathrm{pH}$ diminuíram de 4,5 a 6,0, nas águas naturais, para de 3,0 a 6,0, nas águas obtidas nos piezômetros, e os valores de condutividade elétrica aumentaram de 10 a $55 \mathrm{uS} / \mathrm{cm}$ para de 400 a $1000 \mathrm{uS} / \mathrm{cm}$.

O potássio, cálcio e magnésio foram os cátions em solução que passaram para a água subterrânea em concentrações maiores, entre 2,0 e $270 \mathrm{mg} / 1,20,0$ e 40,0 mg/l, e 12,0 e $210,0 \mathrm{mg} / \mathrm{l}$, respectivamente, e tiveram como principal fonte a própria vinhaça.

Os cátions manganês, ferro e alumínio, solúveis, apresentaram teores com valores muito mais altos do que nas águas obtidas nas cacimbas, entre 5,0 e 20,0 mg/l, 0,005 e $60,0 \mathrm{mg} / \mathrm{l}$, e 0,02 e $23,0 \mathrm{mg} / \mathrm{l}$, respectivamente. Eles foram lixiviados da zona não saturada para o aqüífero, sendo a causa de sua mobilização, provavelmente, a alteração das condições de $\mathrm{pH}$ da zona não-saturada pela vinhaça.

Entre os ânions, apenas o cloreto, que praticamente não reagiu na zona nãosaturada, atingiu a água subterrânea em concentrações altíssimas, entre 4,0 e 640,0 mg/l. O bicarbonato apresentou aumento na sua concentração, propiciada pela grande concentração de $\mathrm{CO}_{2}$ gerada pela biodegradação da matéria orgânica existente na vinhaça. Outros ânions 
presentes na vinhaça, como o sulfato e o ortofosfato, foram retidos na zona não-saturada por adsorção, ou formaram compostos complexos pouco solúveis.

O carbono e o nitrogênio, principais componentes da vinhaça, sofreram uma intensa atividade microbiana e foram degradados no primeiro metro do solo, passando apenas uma pequena parcela destes compostos para a água subterrânea.

Assim, as águas subterrâneas da área de estudo apresentaram-se bicarbonatadas sódicas em condiçóes naturais. Sob o efeito da vinhaça, passaram a ser cloretadas potassicas, evoluindo, com o tempo para cloretadas magnesianas, e finalmente para cloretadas cálcicas.

Entretanto, a maior preocupação residiu nos elementos e compostos químicos que possuíam concentraçóes acima dos padrões de potabilidade para consumo humano, determinados pelas Organização Mundial de Saúde (OMS), Enviromental Protection Agency (EPA) e Ministério da Saúde (MS): o nitrogênio amoniacal, encontrado com valores entre $>0,005$ e $9,8 \mathrm{mg} / \mathrm{l}$, o magnésio, entre 12,0 e $210,0 \mathrm{mg} / \mathrm{l}$, o alumínio, entre $>0,02$ e 23,0 $\mathrm{mg} / \mathrm{l}$, o ferro, entre $>0,005$ e $60,0 \mathrm{mg} / \mathrm{l}$, o manganês, entre 5,0 e $60,0 \mathrm{mg} / \mathrm{l}$,e o cloreto, entre 4,0 e $640,0 \mathrm{mg} / \mathrm{l}$.

Os resultados obtidos nesta pesquisa caracterizam claramente os impactos que a infiltração da vinhaça causa sobre a água subterrânea, tornando-a inadequada para o consumo humano.

Ainda vale ressaltar que a metodologia utilizada nesta pesquisa está sendo aplicada pela CETESB, para a elaboração da legislação que permitirá a proteção das águas subterrâneas. 